DOI

\title{
АНАЛІЗ КЛІНІКО-ЕПІДЕМІОЛОГІЧНИХ АСПЕКТІВ ГІПЕРПЛАСТИЧНИХ ПРОЦЕСІВ ЕНДОМЕТРІЮ ЖІНОК ІЗ ЗАСТОСУВАННЯМ БАГАТОПАРАМЕТРИЧНОЇ НЕЙРОМЕРЕЖЕВОЇ КЛАСТЕРИЗАЦІї
}

\author{
ФП. Р. Сельський, А. Ф. Слива, В. В. Слива \\ ДВНЗ «Тернопільський державний медичний університет імені І. Я. Горбачевського МОз України»
}

\begin{abstract}
РЕЗЮМЕ. 3 метою підвищення ефективності діагностики гіперпластичних процесів ендометрія у жінок перименопаузального віку було проведено ретроспективний аналіз 52 карт стаціонарного хворого жінок, які перебували на лікуванні в гінекологічних відділеннях Тернополя і області. У відповідності з патогістологічним висновком 1 групусклали 28 жінокз зростоюгіперплазієюендометрія, 2 групу-24жінкизкомплексноюгіперплазією ендометрія. В групу порівняння увійшли 12 соматично здорових жінок. Середній вік хворих 1 групи - $(47,0 \pm 1,0)$ років, 2 групи - $(56,0 \pm 1,5)$ років. 3 метою поглибленого аналізу показників застосовано багатопараметричну нейромережеву кластеризацію. Встановлено, що до факторів ризику розвитку гіперпластичних процесів ендометрія у жінок перименопаузального періоду належать неблагополучні соціально-економічні фактори: проживання в сільській місцевості, тяжкі умови праці, шкідливі звички та обтяжений акушерсько-гінекологічний анамнез, 3 і більше вагітностей, велика кількість (4 і більше) акушерсько-гінекологічних втручань, використання внутрішньоматкової контрацепції. У жінок з різними видами гіперплазії ендометрія клімактеричний синдром перебігав середньотяжко чи тяжко з нейровегатативними, ендокринно-обмінними та психоемоційними проявами. Серед коморбідних станів найчастіше спостерігали дисгормональну патологію молочних залоз та порушення гепатобіліарного тракту.

КЛЮчОВІ СЛОВА: гіперпластичні процеси ендометрія, клімактеричний синдром, перименопаузальний вік, дисфункційні маткові кровотечі, коморбідні стани, нейромережева кластеризація.
\end{abstract}

Вступ. Частота гіперпластичних процесів ендометрія (ГЕ) за останні 10 років зросла з 2,1 до 3,8 \%. На ГЕ страждає 16-46 \% жінок пізнього репродуктивного та пременопаузального віку. Відомо, що до 48 \% випадків раку ендометрія в пременопаузі виникає внаслідок малігнізації гіперплазії ГЕ. За прогнозами експертів ВООЗ, до 2016 року відсоток жіночого населення світу старше 45 років досягне $46 \%$. Щороку кількість жінок, що перебувають в перименопаузальному віці, збільшується на 2,5 млн, а до 2020 року ця цифра досягне $47 \mathrm{млн}[4,5]$.

Не зважаючи на велику кількість досліджень в даному напрямку, недостатньо вивченими залишаються фактори ризику, клінічні особливості перебігу та вплив супутньої патології при різних видах ГПЕ у жінок перименопаузального віку, що обґрунтовує високу актуальність даної проблеми.

Мета дослідження. Проаналізувати клінікоепідеміологічні аспекти гіперпластичних процесів ендометрія для підвищення ефективності діагностики цієї патології у жінок перименопаузального віку на основі поглибленого аналізу клініко-анамнестичних даних при різних видах гіперплазії із застосуванням багатопараметричної нейромережевої кластеризації.

Матеріал і методи дослідження. Проведено ретроспективний аналіз 52 карт стаціонарного хворого і біопсій, взятих у жінок перименопаузального віку, які перебували на обстеженні в гінекологічних відділеннях лікувальних закладів Тернополя та області. Проаналізовано: вік хворих, соціально-економічні фактори, акушерськогінекологічний анамнез, клінічні особливості перебігу клімактеричного синдрому та коморбідні стани у жінок з різними видами гіперплазії.

Патогістологічний діагноз верифікований клінічно та гістологічно з врахуванням класифікації гіперпластичних процесів ендометрія ВООЗ 1994 p. [3].

Контрольну групу становили 12 соматично здорових жінок віком $(45,5 \pm 0,7)$ років.

Математичний аналіз даних проведений за допомогою методів варіаційного, кореляційного аналізу з використанням стандартного пакета прикладних програм Microsoft Excel.

Для більш глибокого аналізу показників 3 метою прогнозування перебігу захворювання застосований нейромережевий підхід з використанням надбудови NeuroXL Classifier для програми Microsoft Excel $[8,9]$. Для алгоритму нейромережевої кластеризації обрано параметри, запропоновані програмою, та кількість кластерів, рівну трьом.

Результати й обговорення. Нами було проведено ретроспективний аналіз карт стаціонарного хворого 52 жінок. У відповідності з патогістологічним висновком, 1 групу складали 28 жінок з простою гіперплазією ендометрія (ПГЕ); 2 групу - 24 жінки 3 комплексною гіперплазією ендометрія (КГЕ).

Середній вік хворих 1 групи - $(47,0 \pm 0,7)$ років, 2 групи - $(56,0 \pm 1,2)$ років. 
Огляди літератури, оригінальні дослідження, погляд на проблему

Як правило, менопаузальний вік $\epsilon$ періодом найбільшої соціальної активності жінки в сучасних умовах, тому неблагополучні соціальноекономічні умови можна віднести до факторів ризику ускладненого періоду перименопаузи з розвитком різних видів ГПЕ.

Серед обстежених хворих 2/3 жінок проживали в сільській місцевості. Очевидно, це зумовило низький ступінь звертань до лікувальних закладів та своєчасної профілактики захворювання. Крім того, 18 \% жінок з ПГЕ та майже 21 \% з КГЕ відмічають важкі чи шкідливі умови праці протягом життя. Важливу роль відіграє і наявність шкідли-

вих звичок, які спостерігали майже в $11 \%$ та $17 \%$ хворих 1 та 2 груп відповідно (табл. 1).

Проведений нами аналіз анамнезу встановив, що майже у половини жінок кількість вагітностей перевищувала три, що в 2,5 раза більше, ніж в групі порівняння. Крім того, кількість перенесених акушерсько-гінекологічних втручань та відсоток використання внутрішньоматкової контрацепції був достовірно $(\mathrm{P}<0,05)$ вищим у жінок з ПГЕ та КГЕ, ніж у жінок без гіперплазії. Поряд з тим, безпліддя виявлено у $2((7,14 \pm 5,0) \%)$

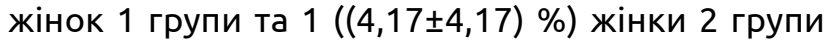
(табл. 2).

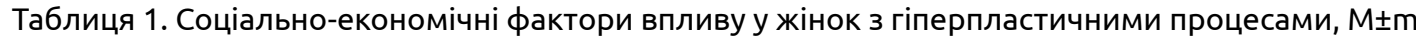

\begin{tabular}{|l|c|c|c|}
\hline \multirow{2}{*}{ Критерії } & \multicolumn{3}{|c|}{ Кількість жінок, \% } \\
\cline { 2 - 4 } & $\begin{array}{c}\text { ПГЕ } \\
(\mathrm{n}=28)\end{array}$ & $\begin{array}{c}\text { КГЕ } \\
(\mathrm{n}=24)\end{array}$ & $\begin{array}{c}\text { ГП } \\
(\mathrm{n}=12)\end{array}$ \\
\hline Місце проживання & $71,4 \pm 8,7$ & $70,8 \pm 9,5$ & $67,7 \pm 14,2$ \\
\hline Тяжкі умови праці & $17,9 \pm 7,4$ & $20,8 \pm 8,5$ & $8,3 \pm 8,3$ \\
\hline Шкідливі звички & $10,7 \pm 6,0$ & $16,7 \pm 7,8$ & $8,3 \pm 8,3$ \\
\hline
\end{tabular}

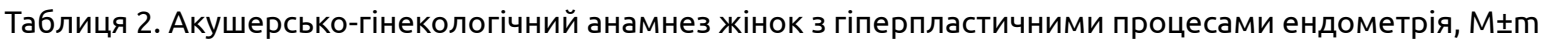

\begin{tabular}{|l|c|c|c|}
\hline \multicolumn{1}{|c|}{ Критерії } & \multicolumn{2}{|c|}{ Кількість жінок, \% } \\
\cline { 2 - 4 } & $\begin{array}{c}\text { ПГЕ } \\
(\mathrm{n}=28)\end{array}$ & $\begin{array}{c}\text { КГЕ } \\
(\mathrm{n}=24)\end{array}$ & $\begin{array}{c}\text { ГП } \\
(\mathrm{n}=12)\end{array}$ \\
\hline Кількість вагітностей, $\leq 3$ & $42,9 \pm 9,5$ & $45,8 \pm 10,4$ & $16,7 \pm 11,2$ \\
\hline Кількість акушерсько-гінекологічних втручань, $\leq 4$ & $60,7 \pm 9,4$ & $62,5 \pm 10,1$ & $25,0 \pm 13,1$ \\
& & & $\begin{array}{c}\mathrm{P}_{1-3}<0,05 \\
\mathrm{P}_{2-3}<0,05\end{array}$ \\
\hline Внутрішньоматкова контрацепція & & & $8,3 \pm 8,3$ \\
& & $37,5 \pm 10,1$ & $\mathrm{P}_{2-3}<0,05$ \\
\hline Безпліддя & $21,4 \pm 7,9$ & & 0 \\
\hline
\end{tabular}

Аналіз клінічного перебігу перименопаузального періоду встановив, що середньотяжкий та тяжкий ступінь клімактеричного синдрому відмічався достовірно частіше у жінок з ПГЕ $(P<0,001, P<0,01)$ та з КГЕ $(\mathrm{P}<0,05, \mathrm{P}<0,01)$, тоді як у жінок групи порівняння вірогідно частіше $(P<0,001)$ спостерігались легкі форми.

В межах ретроспективного аналізу хворих нами виявлено наступні клінічні ознаки клімактеричного синдрому: дисфункційні маткові кровотечі (100\%), урогенітальні порушення (30\%), дратівливість (90\%), втомлюваність (80 \%), депресія (70\%), головний біль (65\%), припливи (70\%), збільшення маси тіла (29 \%). Достовірної різниці клінічних ознак залежно від виду гіперплазії чи віку хворих не виявлено (табл. 3).

Відомо, що ГПЕ найчастіше розвиваються на фоні зниження адаптаційних можливостей, порушення обмінних процесів, розладів різних ланок гіпоталамо-гіпофізарно-яєчникової системи, гіперестрогенемії зумовлених, зокрема, і віковими змінами, що особливо характерно в період пре-та ме- нопаузи $[4,5,7]$. Відомо також, що ризик гіперплазії підвищується при деяких коморбідних станах, наприклад, ожирінні, діабеті та артеріальній гіпертензії, які опосередковано, через змінений стероїдогенез, призводять до гіперестрогенії і виникнення гіперпластичних процесів ендометрія $[1-3,6]$. Крім того, негативно впливають патологія гепатобіліарної системи, шлунково-кишкового тракту, щитоподібної залози і порушення імунітету.

Нами встановлено, що майже в 1/3 жінок 3 різними гіперпластичними процесами ендометрія були дисгормональна патологія молочних залоз та захворювання гепатобіліарного тракту. У 20 \% всіх обстежених мали місце порушення серцевосудинної системи. Хвороби ендокринної системи і обміну речовин, серед яких значну частку складали ожиріння і цукровий діабет, виявлено у 18 \% жінок з ПГЕ та у $17 \%$ - з КГЕ. Патологію ШКТ виявлено у 3

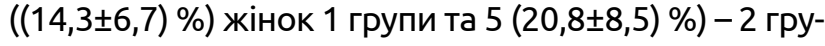
пи. Хвороби сечовидільної системи спостерігали в 25 \% жінок з КГЕ та у $14 \%$ - з ПГЕ (табл. 4). 
Огляди літератури, оригінальні дослідження, погляд на проблему

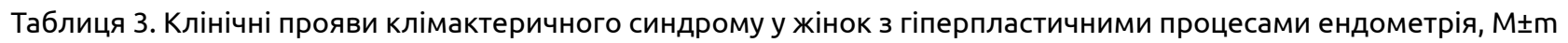

\begin{tabular}{|c|c|c|c|}
\hline \multirow[b]{2}{*}{ Клінічні ознаки } & \multicolumn{3}{|c|}{ Кількість жінок, \% } \\
\hline & $\begin{array}{c}\text { ПГЕ } \\
(n=28)\end{array}$ & $\begin{array}{c}\mathrm{K} \Gamma \mathrm{E} \\
(n=24)\end{array}$ & $\begin{array}{c}\Gamma П \\
(n=12)\end{array}$ \\
\hline Дисфункційні маткові кровотечі & 100 & 100 & 100 \\
\hline Урогенітальні порушення & $21,4 \pm 7,9$ & $33,3 \pm 9,8$ & $8,3 \pm 8,3$ \\
\hline Дратівливість & $89,3 \pm 5,9$ & $91,7 \pm 5,8$ & $58,3 \pm 14,9$ \\
\hline Втомлюваність & $75,0 \pm 8,3$ & $83,3 \pm 7,8$ & $50,0 \pm 15,1$ \\
\hline Депресія & $64,3 \pm 9,2$ & $75,0 \pm 9,0$ & $66,7 \pm 14,2$ \\
\hline Головний біль & $60,7 \pm 9,4$ & $70,8 \pm 9,5$ & $41,7 \pm 14,9$ \\
\hline Припливи & $67,9 \pm 8,9$ & $75,0 \pm 9,0$ & $41,7 \pm 14,9$ \\
\hline Збільшення маси тіла & $28,6 \pm 8,7$ & $29,2 \pm 9,5$ & $16,7 \pm 11,2$ \\
\hline
\end{tabular}

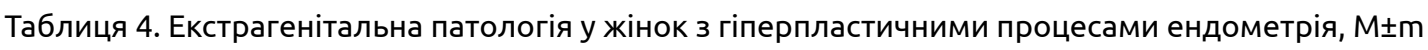

\begin{tabular}{|l|c|c|c|}
\hline \multicolumn{1}{|c|}{ Патологія } & \multicolumn{3}{c|}{ Кількість жінок, \% } \\
\cline { 2 - 4 } & $\begin{array}{c}\text { ПГЕ } \\
(\mathrm{n}=28)\end{array}$ & $\begin{array}{c}\text { КГЕ } \\
(\mathrm{n}=24)\end{array}$ & \multicolumn{1}{c|}{$(\mathrm{n=12)}$} \\
\hline Дисгормональна патологія молочних залоз & $32,1 \pm 8,9$ & $33,3 \pm 9,8$ & $8,3 \pm 8,3$ \\
\hline Захворювання серцево-судинної системи & $21,4 \pm 7,9$ & $20,8 \pm 8,5$ & $16,7 \pm 11,2$ \\
\hline Хвороби ендокринної системи і обміну речовин & $17,9 \pm 7,4$ & $16,7 \pm 7,8$ & $8,3 \pm 8,3$ \\
\hline Патологія шлунково-кишкового тракту & $14,3 \pm 6,7$ & $20,8 \pm 8,5$ & $25,0 \pm 13,1$ \\
\hline Хвороби сечовидільної системи & $14,3 \pm 6,7$ & $25,0 \pm 9,0$ & $8,3 \pm 8,3$ \\
\hline Захворювання гепатобіліарного тракту & $28,6 \pm 8,7$ & $29,2 \pm 9,5$ & $25,0 \pm 13,1$ \\
\hline
\end{tabular}

3 метою встановлення значення поєднаних змін тих чи інших параметрів для прогнозу прогресування захворювання здійснено нейромережеву кластеризацію на основі таких даних анамнезу пацієнток з ПГЕ та КГЕ: ступінь тяжкості клімактеричного синдрому I - легкий, II - середній, III - тяжкий, Iгг - дратівливість, Uг - урогенітальні порушення, Fat - втомлюваність, Dep - депресія, GM - дисгормональна патологія молочних залоз, End - захворювання ендокринної системи і обміну речовин, Нер - захворювання гепатобіліарної системи. Обрані три кластери. На рисунках 1 та 2 наведено деякі результати виконання програми для пацієнтів з ГПЕ.

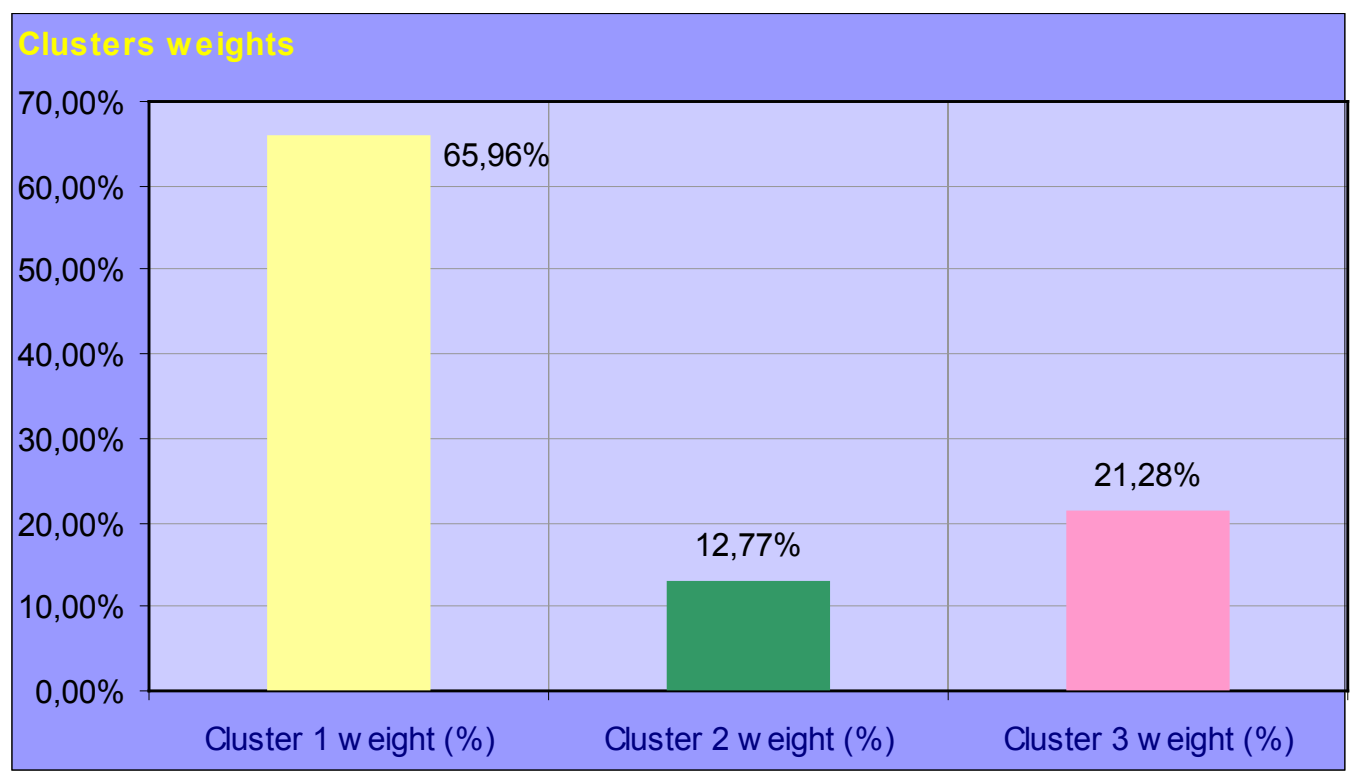

Рис. 1. Частки кластерів - відсотки пацієнток, які потрапили у певний кластер. 


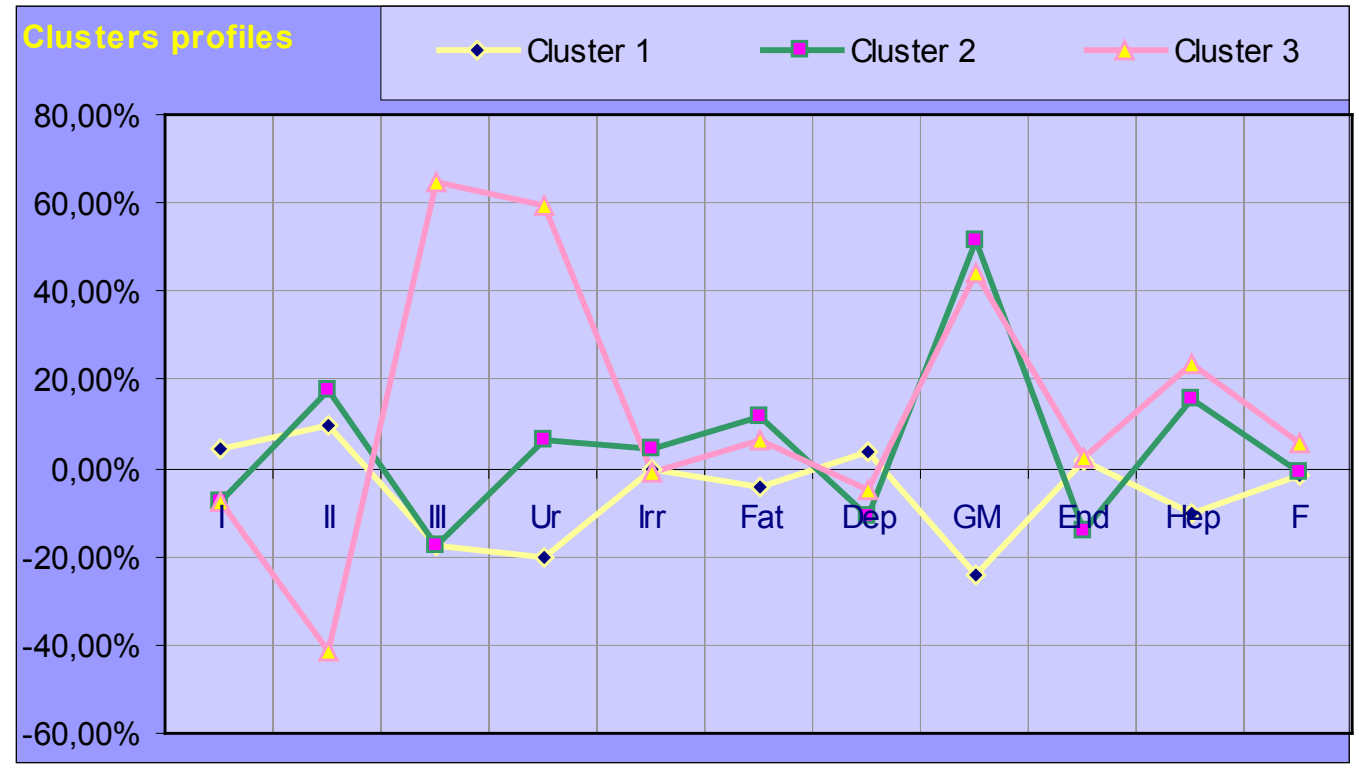

Рис. 2. Кластерний портрет - середні значення параметрів в межах розподілених кластерів.

Найбільша відносна частка пацієнток з КГЕ, тобто прогресуванням захворювання, виявлялась у 3 кластері. Показник форми захворювання ("F") фіксувався навпроти кожного хворого як "1" при ПГЕ та "2" у випадку КГЕ. За допомогою кластерного портрета (рис. 2) можна визначити, що на 3 кластер, поряд із найвищим значенням $F$, припадає і найбільше хворих з тяжким ступенем клімактеричного синдрому з урогенітальними порушеннями та патологією гепатобіліарної системи. При цьому інші анамнестичні показники у даному кластері не перевищували аналогічні показники 1-2 кластерів.

Таким чином, порівняльний аналіз середніх значень відносних та пересічних анамнестичних показників $\epsilon$ первинним інструментом, який не дає змоги встановити значення поєднання зміни тих чи інших параметрів, включно із достовірно відмінними показниками для прогнозування прогресування захворювання. Водночас, аналіз кластерних портретів виявив, що поєднання тяжкого ступеня клімактеричного синдрому 3 урогенітальними порушеннями та патологією гепатобіліарної системи дає підставу прогнозувати найбільший ризик розвитку КГЕ у обстежених пацієнток.

Висновки. 1. До факторів ризику розвитку гіперпластичних процесів ендометрія у жінок в перименопаузальному періоді належать неблагополучні соціально-економічні фактори: прожи- вання в сільській місцевості, тяжкі умови праці, шкідливі звички.

2. Гіперпластичні процеси ендометрія достовірно частіше розвиваються у жінок з трьома і більше вагітностями, великою кількістю (4 і більше) акушерсько-гінекологічних втручань та використанням внутрішньоматкової контрацепції в анамнезі.

3. У жінок з різними видами гіперпластичних процесів ендометрія клімактеричний синдром перебігав середньотяжко чи тяжко з нейровегатативними, ендокринно-обмінними та психоемоційними проявами.

4. Серед коморбідних станів у жінок перименопаузального періоду з гіперпластичними процесами ендометрія найчастіше спостерігались дисгормональна патологія молочних залоз та порушення гепатобіліарного тракту.

5. На основі аналізу поєднаних змін за допомогою багатопараметричної нейромережевої кластеризації встановлено, що при прогнозуванні прогресування гіперпластичних процесів ендометрія необхідно враховувати саме поєднання тяжкого ступеня клімактеричного синдрому 3 урогенітальними порушеннями та патологією гепатобіліарної системи у пацієнток.

Перспективи подальших досліджень. Бачиться перспективним використання інноваційних інформаційних методик для покращення диференційної діагностики гіперпластичних процесів ендометрія. 
Огляди літератури, оригінальні дослідження, погляд на проблему

\section{ЛІТЕРАТУРА}

1. Вихляева Е. М. Гиперпластические процессы эндометрия / Е. М. Вихляева, Б. И. Железное, В. Н. Запорожан // Руководство по эндокринной гинекологии. - М. : МИА, 2002. - С. 603-710.

2. Волкова Н. И. Здоровье женщин в перименопаузе. Теория и практика / Н. И. Волкова // Жур. акуш. и жен. болезней. - 2004. - Вып. 2. - Т. LII. - С. 54-59.

3. Кузнецов И. В. Гиперпластические процессы эндометрия / И. В. Кузнецов. - М. : Медицина, 2009. -48 c.

4. Климактерический период и менопауза // Рациональная фармакотерапия в акушерстве и гинекологии : руководство для практ. вр. - М., 2005. - Гл. 48. С. 593-603.

5. Менопауза и связанные с ней расстройства / Ф. Карр [и др.] // Акушерство, гинекология и здоровье женщины : пер. с англ. М., 2005. - Разд. 12. - С. 156-163.

6. Чеботникова Т. В. Клинические и метаболи- ческие проявления климактерического синдрома / Т. В. Чеботникова, Г. А. Мельниченко, Е.Н. Андреева // Пробл. репродукции. - 2004. - № 2. - С. 69-77.

7. Metabolic and vascular effect of progestins in postmenopausal women: implications for cardioprotection / G. M. C. Rosano, C. Vitale, A. Silvestri, M. Fini // Maturitas. 2003. - Vol. 46 (Suppl. 1). - P. 17-29.

8. Shepherd A. J. Second-Order Methods for Neural Networks : Fast and Reliable Training Methods for MultiLayer Perceptrons / A. J. Shepherd. - London : Springer, 1997. - 342 p.

9. Марценюк В. П. Нейромережеве прогнозування складання студентами-медиками ліцензійного інтегрованого іспиту “Крок 1" на основі результатів поточної успішності та семестрового комплексного тестового іспиту / В. П. Марценюк, А. В. Семенець, О. О. Стаханська // Медична інформатика та інженерія. - 2010. № 2. - С. 57-62.

\section{CLINICAL AND EPIDEMIOLOGICAL ASPECTS OF ENDOMETRIAL HYPERPLASIA IN PERIMENOPAUSAL WOMEN}

\section{Ya. Gorbachevsky Ternopil State Medical University, Ternopil, Ukraine}

SUMMARY. To improve the efficiency of diagnosis of endometrial hyperplastic processes in perimenopausal women was conducted a retrospective analysis of 52 cards inpatient women who were treated at gynecological departments of Ternopol region. According to the histopathological finding 1st group included 28 women with simple endometrial hyperplasia; 2nd group - 24 women with complex endometrial hyperplasia. Comparison group consisted of 12 somatically healthy women. The average age of patients of group $1-(47,0 \pm 1,0)$ years, group $2-(56,0 \pm 1,5)$ years. In order depth analysis parameters neural network clustering applied. Established that the risk factors for hyperplastic processes of endometrium in women of perimenopausal period include disadvantaged socio-economic factors: residence in rural areas, difficult working conditions, bad habits and burdened obstetric and gynecological history, 3 or more pregnancies, a large number (4 and more ) obstetrical interventions, use of intrauterine contraception. In women with different types of endometrial hyperplasia the course of the climacteric syndrome was moderate and severe with neuro-vegatative, endocrine-metabolic, and psycho-emotional manifestations. Among the comorbid conditions often seen dyshormonal pathology of breast and hepatobiliary tract disorders.

KEY WORDS: endometrial hyperplasia, menopausal syndrome, perimenopausal age, dysfunctional uterine bleeding, comorbid diseases, neural network clustering. 